\title{
The Influence of News Construction and Netizen Response to the Hoax News in Online Media
}

\section{Pengaruh Konstruksi Berita dan Respon Netizen terhadap Berita Hoaks di Media Online}

\author{
Dendy Suseno Adhiarso ${ }^{1}$, Prahastiwi Utari ${ }^{1}$, Sri Hastjarjo ${ }^{1}$ \\ ${ }^{1}$ Magister of Communication Science, FISIP, Universitas Sebelas Maret Surakarta, Jl. \\ Ir. Sutami No. 36A, Kentingan Jebres, Surakarta 57126, Indonesia \\ *Corresponding author, e-mail: dendysuseno@gmail.com
}

\begin{abstract}
This study aims to determine the effect of news in online media on the thoughts and behavior of a person, because the impact is very strong in shaping public opinion. This study uses theory of mass communication, news construction, netizen response, online media. The research method used quantitative descriptive analysis with online data collection techniques. Conclusion of research (1) News construction have positive effect to reporting hoax in online media, meaning that news construction which is loaded and created by online media will influence hoax news dissemination. (2) The netizen response positively affects the news of hoaxes in the online media, meaning more and more netizens respond to hoax news, hoax news will be wider. (3) News construction and netizen responses have a positive and significant influence on hoax news in media online, meaning that these two variables give a significant influence in the preaching of hoax in online media.
\end{abstract}

Keywords: News Construction, Netizen Response, Hoax News.

\begin{abstract}
Abstrak
Penelitian ini bertujuan untuk mengetahui pengaruh berita di media online terhadap pemikiran dan perilaku seseorang, karena dampaknya sangat kuat dalam membentuk opini publik. Penelitian ini menggunakan teori komunikasi massa, konstruksi berita, respon netizen, dan media online. Metode penelitian menggunakan analisis deskriptif kuantitatif dengan teknik pengumpulan data secara online. Kesimpulan penelitian: (1) Konstruksi berita berpengaruh positif terhadap pemberitaan hoaks di media online, artinya konstruksi berita yang dimuat dan diciptakan media online akan mempengaruhi penyebaran berita hoaks. (2) Respon netizen berpengaruh positif terhadap berita hoaks di media online, artinya semakin banyak netizen merespon berita hoaks, maka peredaraan berita hoaks akan lebih luas. (3) Konstruksi berita dan respon netizen memiliki pengaruh positif dan signifikan terhadap berita hoaks di media online, artinya kedua variabel tersebut memberikan pengaruh yang cukup signifikan dalam pemberitaan hoaks di media online.
\end{abstract}

Kata Kunci: Konstruksi Berita, Respon Netizen, Berita Hoaks.

Copyright ( 2018 Universitas Semarang. All rights reserved.

\section{Introduction}

The mass media is the work of human culture that is increasingly growing and expanding. The mass media as a means to spread the message/information to the public. Along with the development of information emerging, today makes society increasingly takes the role of the mass media. The media presents the events surrounding the life of company both nationally and internationally, so that with the news of human knowing, 
understanding, and understand everything that is happening around and in the world (Wimmer \& Dominick, 2013). News items presented in the mass media is an attraction that can invite the curiosity of the reader or the public. News that arise can be events, events, opinions, ideas and so on. News also can attract the reader's attention because of events there is tremendous news, important, or will affect their lives. So the news can also invite readers because it involves emotions, empathy, and sympathy (Oliver, Dillard, Bae, \& Tamul, 2012).

The mass media include electronic and print media. Electronic mass media such as television, radio and internet. Online media has an important role that lies in its ability to present news about the development of the society which could affect modern life at this time (Nguyen, 2010). Online media is a repository of information about the event or events experienced by the people in public life. The mass media in presenting information to the public put the facts on the ground. In the world, there is a saying that tells reporters that the fact it is sacred. The meaning of this phrase is an invitation for journalists to maintain objectivity, which treats the effects correspond to actual events. However, the news that appeared in the mass media is no longer reflect the truth of events there, because it has undergone the process of construction of reality. When the news appeared not fit the facts, it falls into the category of news contains a lie.

A growing phenomenon in today's society is the news spread hoax. The issue of child abduction by the perpetrators pretended mode crazy unsettling and went viral on online media. More than one week, some people suffering from mental illnesses of various regions are victims of violence of citizens who believe the issue of chain messages about child abduction. Fear exists in the minds of parents these days. The reason is none other than the height of the problem of a kidnapping of childrencirculating through chain messages on their mobile phones. A grandfather residents of Pontianak, West Kalimantan, Maman Budiman (53 years old) died after becoming victims of mass anger because of the spread of news about child abduction hoax with organ sales mode ("Innalillahi... Dikira Penculik Anak, Maman Tewas Dihajar Massa: Okezone News"). Visits victim to the village to visit his grandchildren. However, on arrival at the victim did not know exactly his house so that confusion. Confusion victim makes people suspicious, because of the victim of suspicious movements, the community itself and direct anarchist action. Not only in Pontianak but the issue of child abduction also casualties in Serang, Banten. A strong suspicion that if the victim was mentally ill so that the victim died after being a victim of anger of hundreds of people on the street (Liputan6.com, n.d.).

In addition to child abduction, treason was again bustling issue a warm conversation. Especially after the arrest of 10 leaders for alleged treason. Rumors of the plot when Chief General Tito Karnavian sensed movement that will infiltrate the demonstration 25 of November and 2 of December. Tito was early vowed to crack down on anyone who violates the law to aspiration in the protest later. Besides social media lately crowded with news and information related to the issue of religion with the action that call 'Bela Islam III' in Jakarta 2 of December last year ("Pernyataan Lengkap Kapolri Soal Larangan Aksi 2 Desember dan Agenda Makar,” n.d.). Many persons are not responsible for disseminating information hoaxes and nuanced racial issues in online media. Society considers what appears in the news is a reality, by promoting objectivity. Whereas in the news reporters always tucked subjectivity. So the story that presents an event seen not by fact or truth. In the end, people assume that the facts of social reality, regardless of whether or not the contents of the message. As a 
result of false news that causes individuals very easily influenced by media messages because the media is compelling in shaping public opinion.

Nuanced, interesting story in the media a lot of public attention. Utilization of social media and mass media into public places convey the public opinion that is humanitarian or human interest to the issues that develop. With the internet, people can opine good through social media Twitter, Facebook, Path, Line, WeChat, Website, Blog, E-mail and so forth. With the Internet-based media, especially websites allow people to see posts from the news media and cause people to make comments and opinions freely. At that time began to change behavior in society (EB \& SW, 2017).

Servings news and construction of reality that began in viewing that highlight aspect of the press to facilitate the public in remembering certain things. In posting a news media are emphasizes on their ideology. Many aspects of the influence of mass media perspective. They edit, compile a narrative, choose a title to highlight certain aspects and neglect other aspects (McCombs, 2014). In this case the media as a bridge between the community and the world. Routinely mass media provide information about important events that are or have occurred. What the differences occur in the mass media is not an accidental and without intent. Differences in the presentation we know the name of this media framing is something that has been approved by internal parties medium itself. Many things affect the grain of news in the mass media to the public. Journalists as the first in the production of news of course quite a role in influencing the content of the story. But in addition to writers, there are also more right parties in determining the substance of the news and choose what should be, may, or may not appear in the story. They are certainly the ranks of editors and owners of capital who have full power against the media. Based on the above exposure, researchers want to know how the influence of online media for human life, because online media has an important role that lies in its ability to present news about the development of society. In addition, news that appears in the online media is very strong in shaping public opinion. While the basic theory or concepts used in this study are:

\section{Message Communications}

According to Griffin is managing message communications with the aim of creating meaning. If we look at the definition is rather broad, but appropriate if we will determine what happens in every stage of the communication, which seeks to determine as to whether a communication process will succeed or fail in the context of interpersonal communication and communication within a group. In other words, if we consider communication as a destination, either persuade, inform, or entertain then we communicate with intent, and we can achieve our goals only by interacting with someone (Griffin et al., 2010).

Meanwhile, according to the traditional perspective Littlejohn (functionalist and objective), organizational communication tend to emphasize the message handling activities contained within an organizational boundary. The focus is to receive, interpret and act on information in a context (Littlejohn \& Foss, 2010). The emphasis is on communication as a tool that allows people to adapt to their environment. Meanwhile, when looked at from the perspective of interpretive, organizational communication is the process of creation of meaning for the interaction which is the organization. Communication is the process of creation of meaning for the interaction that creates, maintain and transform organizations. 


\section{Mass Communication}

Mass communication is communication through the mass media, including electronic media, namely film, television and radio, print media, namely newspapers, magazines, periodicals, and books. Definition of mass communication the most simple: mass communication on a large number (Baran \& Davis, 2011). Jay Black and Frederick C. mentions that mass communication is a process in which the messages appeared widely spread to the broad mass of the message recipient, anonymous, and heterogeneous (Napoli, 2010). Size, in this case, means more than just a collection of people who are physically adjacent. Anonymous says that individuals who receive the message tend to be strangers to one another. Heterogeneous means that the message is for people of various status, occupation, and profession with different characteristics to one another rather homogeneous recipient (Barker \& Gower, 2010).

\section{News Construction}

The media itself affects the audience. Thus meaning that marks the important effect of mass media use by the public is the awareness and knowledge of a topic or issue. The emergence of consciousness and experience are often made people aware of as a result of which it is the primary purpose of mass media through the presentation of a given topic result of the construction of reality (Lau, 2012). Function of the media is to inform, educate, influence and provide entertainment (Soroka, 2012).

The mass media is a tool to construct reality according to constructivist views. The sociologist Peter L. Berger and Thomas Luckmann introduced the term construction of reality (Berger, 2011). They describe the social process through action and interaction, where individuals create a continuous reality and subjectively experienced together. The social development comes from constructivist philosophy. Constructivism is a view that reality is the result of human construction (Fosnot, 2013). This understanding is there to interpret the reality of the world because of a social relationship between the individual and the surrounding environment. Constructivism considers that reality is the result of an individual, then build their knowledge of reality that emerged was based on the structure of pre-existing knowledge, or he understands it. Berger and Luckmann said constructivism as this is what they call a social construction. Social development occurs in the mass media.

According to Berger and Luckmann about theory and social construction approach, the reality happens through three social processes; namely objectivation objective reality is the reality that emerges from the experience of the world undergoing an institutional process. So objectivation objective reality objectively is outside the individual and considers this fact as fact. Objective reality itself consists of symbolic reality and objective reality in various forms. While the subjective reality is the reality that is formed as the process of re-absorption of objective reality and symbolically to the individual through the process of internalization. In the process of internalization, the current reality by the understanding of each person to the reality of what happened. This process occurs in two-way communication between objective reality and ideology of the individual. The thinking of any one person to another would have differences. This difference arises because many factors that influence the background, for example, religious factors. Individuals that of religion Islam will have a different view of seeing things, because of differences in the teachings of their respective faiths.

In constructivism, information or news to the community in advance through the construction process of reality by the editorial meeting. The paradigm of constructivism sees that the press presentation which is the result of mass media production is also the 
result of the construction of the reality of an event. Assignment reporter, by the ideology of the mass media, is concerned, retelling an event to the public according to the version at the same time a point of view of the journalist. Thus, the news in the mass media and to the public is the reality of an entirely new and different from the reality that exists as a result of the efforts of journalists in constructing reality.

4. Netizen Response

A response can we interpret as a picture memory of observation. According to the book 'Psikologi Komunikasi', before the reply, the man receives sensations from the tool senses (Rakhmat, 1985). The sensation is an early stage in receiving the information. The next stage is the perception, which the process of giving meaning to the sensation/stimuli that elicit a response using the senses. Perception is the experience of the objects, events, or relationships that arise by concluding information and interpret the message (Purwasito, 2017). After the process of sensation and perception, and then comes the response. The response is a response (effect) audience to the message that appears in the media (Jin \& Liu, 2010).

The communication process has several important elements, one of which is the effect. Real shape effect in the communication process is the formation of a change in opinion or attitude/behavior of the audience after receiving a message. Understanding these effects also apply to mass communication, meaning that after a netizen receive messages in the form of news from the media, then the audience will give feedback on the report. Whether the response is hegemonic, negotiation or opposition. In addition, the audience can also respond to messages that appear. The response/effect on the public are:

a. Cognitive Effects

This effect is related to thought or reasoning, so netizens understand and remove the purpose of the message.

b. Affective Effects

This fact is synonymous with feelings. Due to the exposure of the mass media, netizens can feel sad, happy, angry, or disappointed.

c. Conative Effects

This effect is related to the intention, determination, effort, endeavor, which tends to be an activity or action (Park, Stoel, \& Lennon, 2008).

5. Online Media

The media provides an overview of communication tools that have direction and purpose in the various aspects of the community as a whole not only the upper classes only, but the lower classes also involved (Bergemann \& Bonatti, 2011). The term media refers to the number of media that has been there since decades ago and still exist today, such as newspapers, magazines, movies, radio, television, and even the mass media today is the internet. People easily get the actual news quickly via the Internet, such as facebook, twitter, and print media into the online media. Mass media have properties or characteristics that can reach the masses in large numbers and wide, public and able to give popularity to anyone who appears in the media (Street, 2010).

An online word consisting of two syllables, namely on and line. According to Indonesian English dictionary, the word on an ongoing means. While the line says the line, line, rope, line, line, roads, boundaries, outline, departments, fortification, slate, and themes. Online itself is a language of the internet, which means the information can 
be accessed anywhere and anytime. Online media can accommodate news text, image, audio, and video. Unlike the print media that display only text and image.

Online media is media that appeared in the virtual world, Williams Gibson first introduced the term cyberspace in his novel that defines the virtual world that is globally connected reality with computer support, computer-access, multidimensional, artificial, or virtual. The online media is the Internet media such as websites, blogs, and other published/aired in cyberspace, can be read and viewed on the web (Parthasarathi et al., 2012). Online media is a new player in the arena of the Indonesian press, according to multiple sources of online media in Indonesia has been growing since 1994. The online media is a new idea in of media, but online media still follow the old media and often take advantage of old media as a benchmark regarding content on the Internet. Several studies have documented the tendency of online newspapers to repackage material from print publications.

\section{Methodology}

This research uses quantitative descriptive analysis technique. Data collection techniques in this study using online data collection techniques (Ward, Clark, Zabriskie, $\&$ Morris, 2012). The point is an online data collection procedure for searching data through online media such as the Internet or other network media that provides online facilities. Therefore, using quantitative descriptive analysis allows researchers to use online data/information in the form of data and information theory, as quickly or efficiently as possible and academically accountable. Subjects in this study are active netizens using online media and often pay attention to news contained in detik.com. The data collected is a news document that appears in detik.com by capture the news or print the news. While the news period used in netizen sampling is the news period from December 2016 to May 2017 where at 6 months it is the peak of news hoax ahead of regional election or PILKADA DKI Jakarta.

Research Hypothesis

a. The Influence of News Construction on Hoax Reporting in Online Media

The main products in the mass media are the news. News occupies a leading position as one piece of product information on all things that are very useful and beneficial to enlighten civilization of human life towards the better. The realities of events that occur in all aspects of life which include: social, legal, economic, political exclusion, religious. All of it is the main ingredients of a process of news that will come to the community. Principles of journalism who always put aspects of actuality, factuality, impartiality always be the primary reference for all journalists also signs of journalistic ethics regulation or limit the movement of professional writers as a handle. Indeed, to be a story that interests of society, the elements of the value of the news (news value) remains the standard value by reporters because a message that does not have the items of news value would appear flat and monotonous without significant meaning for the community.

Based on the above description, the researcher proposed hypothesis $\mathrm{H} 1$ as follows: H1: News Construction has a positive effect on Hoax Reporting in Online Media b. The Effect of Netizen Response to Hoax Reporting in Online Media

The response came from someone's attitude. The response is a tendency or willingness to behave when faced with certain stimuli. So, talking about the reply or no response in spite of the discussion attitude. Besides definition of reaction is a behavior or attitude that tangible product before detailed understanding, research, influence or 
denial, likes or dislikes as well as the utilization of a particular phenomenon. Three factors that affect a person's response: the first is the person concerned who saw and tried to give the interpretation of what is where attitudes, motives, interests, and expectations affect the person. The second is the response of the target can be a person, thing, or event. The properties of the target usually influence the reaction of individuals who see it. In other words, movement, sound, size, actions, and other characteristics of the target response helps determine how people saw. The third is the factor of the situation; we can see the contextually meaningful response in a situation such as what kind of response will get his attention. The situation is a factor that played a role in the formation or one's response. A reaction about the news content will appear along with understanding the messages emerging media, so the response will significantly influence the story in online media.

Based on the above description, the researcher proposed hypothesis $\mathrm{H} 2$ as follows: H2: Netizen Response Positively Affects Position of Hoax in Online Media

c. The Influence of News Construction and Netizen Response jointly to Hoax News in Online Media

Press the journalistic practices of the mass media constructs reality, and the news is a form of constructed reality. For some people would rate the news as it happens in the news, and the news seemed appropriate objectivity. But if we look deeper into the news, reality or events that occur around us has undergone reconstruction and framing by the media. So appeared meaning of social reality and produce specific meanings, as a journalist as news makers, as well as the press as an institution with journalism practices, can affect reality to conform to the ideological background.

The public may not be aware that the news is the result of the construction of reality, and considered that what they read and hear is the truth. In fact, if carefully further depth, through the mass media journalists have just redefining reality of what happened, so that the reality of actually producing particular meanings. The mass media in the construction process news will prepare the building material that has coherence with the meaning you want to tune in the news for the audience, so the audience can later be, opinionated, and acting by the meaning and purpose of journalists reporting by the mass media.

Formation of news construction can be in the form of good news and bad news. In the first, the object construction news as something that has a good image and better than the real thing. While the shape of the second, object construction news as something that has a bad image even worse than the real thing. From the creation of the story, we can see that the mass media has a significant force.

Based on the above description, the researcher proposed H3 hypothesis as follows: H3: News Construction and Netizen Response have a positive effect on Hoax Reporting in Online Media

Based on the problems that have been described, it can be described framework as follows: 


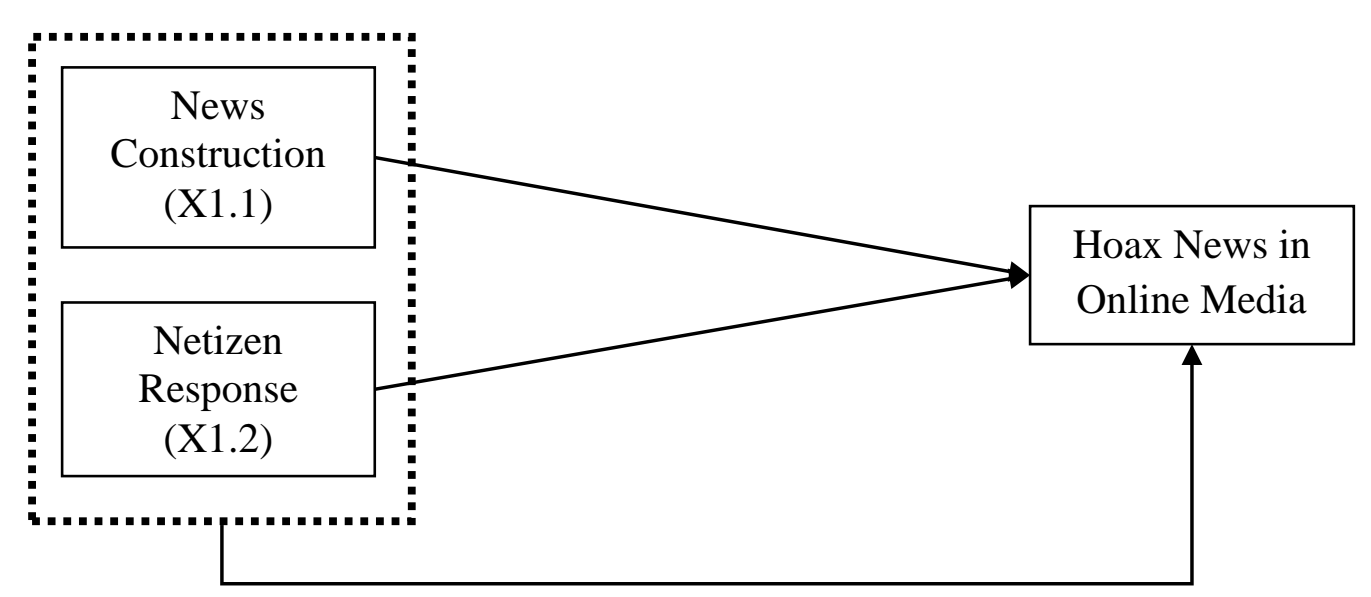

Figure 1. Framework

\section{Result and Discussion}

The results of multiple linear regression analysis using SPSS for windows ver 21 aims to analyze the influence of the press construction variables and the response to the preaching hoax netizens in online media is to see a significant coefficient of determination ( $\mathrm{R}$ Square). In this study, there is a dependent variable, namely the hoax reports in online media, and two independent variables, namely the construction of the news and the response of netizens. Under these conditions, using multiple regression analysis. Of regression, analyses were performed using SPSS version 21 support program for windows which are also used to test the significance of the individual or the t-test then obtain the following table.

\begin{tabular}{|c|c|c|c|c|c|c|}
\hline \multirow{2}{*}{\multicolumn{2}{|c|}{ Model }} & \multicolumn{2}{|c|}{$\begin{array}{c}\text { Unstandardized } \\
\text { Coefficients }\end{array}$} & \multirow{3}{*}{$\begin{array}{c}\text { Standardized } \\
\text { Coefficients } \\
\text { Beta }\end{array}$} & \multirow[b]{2}{*}{$\mathbf{t}$} & \multirow[b]{2}{*}{ Sig. } \\
\hline & & B & $\begin{array}{l}\text { Std. } \\
\text { Error }\end{array}$ & & & \\
\hline 1 & (Constant) & 2.198 & 1.771 & & 2.241 & .002 \\
\hline & Konstruksi.Berita & .145 & .221 & .273 & 2.654 & .001 \\
\hline & Respon.Netizen & .162 & 125 & .541 & 3.295 & .000 \\
\hline
\end{tabular}

\section{Table 1}

Regression Analysis

According to the table above, the regression equation in getting is as follows:

$\mathrm{Y}=2,198+0,162 \mathrm{X} 1+0,145 \mathrm{X} 2$

Information:

$\mathrm{Y}=$ Hoax Coverage in Online Media

$\mathrm{X} 1=$ News Construction

$\mathrm{X} 2=$ Netizen Response

The mathematical model equations show that the influence of netizens response is more dominant than the construction of news to the news hoax in Media Online. What we can see from the regression coefficient is 0.162 netizen response is greater than the regression coefficient 0,145 worth of news construction.

1. Hypothesis Testing

Based on the research paradigm that has been there before, in this study will examine the hypothesis of partial and simultaneous. To test this hypothesis will use statistical tests to multiple regression calculations as quantitative analysis. The results of hypothesis testing based on the analysis that has gone before, we can describe as follows: 
a. The Influence of News Construction on Hoax Reporting in Online Media

In Table 1 shows the results of the partial significance test (t-test) using SPSS version 21 program for Windows. Based on the chart above, we can see that the probability value or sig. its significance is 0.001 or less than 0.05 or $5 \%$. Also based on the analysis results we obtain the value of $t$ count equal to 2,654 bigger than the t-table value of 1.969 . Because of sig $<0.05$ and t-count value is greater than t-table then we can say that the hypothesis positive effect on the construction of news reports in online media hoax evident.

b. The Effect of Netizen Response to Hoax Reporting in Online Media

Table 1 shows the results of the partial significance test (t-test) using SPSS version 21 program for Windows. Based on the chart above, we can see that the probability value or sig. its significance is 0.000 or less than 0.05 or $5 \%$. Also based on the analysis results we obtain t-test value of 3.295 is greater than the t-table value of 1.969. Because of sig $<0.05$ and $t$-count value is higher than t-table then we can say that the hypothesis Response Netizen positive effect on Hoax in Online Media Coverage is evident.

c. The Influence of News Construction and Netizen Response to Hoax Reporting in

Online Media

The results of simultaneous significance test (F-test) using SPSS version 21 program for windows is as follows.

\begin{tabular}{|l|l|r|r|r|r|l|}
\hline \multicolumn{2}{|c|}{ Model } & $\begin{array}{c}\text { Sum of } \\
\text { Squares }\end{array}$ & \multicolumn{1}{c|}{ df } & $\begin{array}{c}\text { Mean } \\
\text { Square }\end{array}$ & F & Sig. \\
\hline 1 & Regression & 147.418 & 2 & 73.709 & 27.245 & .000 (a) \\
\hline & Residual & 78.457 & 29 & 2.705 & & \\
\hline & Total & 225.875 & 31 & & & \\
\hline
\end{tabular}

Table 2

Simultaneous Test Results (Test-F)

Based on the table 2, we know that the probability of significance or its $\mathrm{p}$ value is 0.000 which is smaller than 0.05 or $5 \%$ and the value of f-count of 27.245 is greater than the value of the f-table of 3.879. Thus together construction news and the response of netizens have an active and significant impact on the hoax reports in online media.

2. The Coefficient of Determination (Adjusted $\mathrm{R}^{2}$ )

To measure how far the ability of independent variables in explaining the dependent variable using the coefficient of determination, of the price of $R^{2}$. The fundamental weakness of the utilization of the coefficient of determination is biased against the number of independent variables that we put into the model. Therefore, many researchers advocate for the use of Adjusted $R^{2}$ value when evaluating the best regression model. Results of SPSS data if we see in the following table:

\begin{tabular}{|l|c|r|r|c|}
\hline Model & R & R Square & $\begin{array}{c}\text { Adjusted } \\
\text { R Square }\end{array}$ & $\begin{array}{c}\text { Std. Error } \\
\text { of the } \\
\text { Estimate }\end{array}$ \\
\hline 1 & .808 (a) & .653 & .629 & 1.64481 \\
\hline
\end{tabular}

Table 3

The Coefficient of Determination

Based on the output SPSS model summary or table 3 above, the magnitude of $\mathrm{R}^{2}$ is 0.653 this means that $65.3 \%$ dependent variable of hoax reporting in online media can be explained or influenced by independent variable of news construction and netizen 
response, while the rest $34,7 \%(100 \%-65.3 \%)$ is explained by other causes outside the research model.

\section{Conclusion}

Based on the analysis and discussion, we can conclude:

1. News construction affect positively hoax story in online media, which means that the development of the existing press and created by the online media will affect the spread hoax news in online media.

2. Netizen response affect positively effect on the hoax story in online media, which means that more and more netizens are responding to news hoax, the hoax news distribution will be wider and wilder without referring to journalistic ethics.

3. News construction and netizens response have an active and significant effect on the hoax story in online media, which means that both variables provide considerable influence in the hoax news in online media.

Based on the conclusion of the research can be seen clearly that the news hoax is a common enemy that must anticipate. Public awareness of media literacy should be improved so that it can ward off the danger of general hoax news. The hope of the researcher, there will be more research about this in more depth which will have a significant influence on the environment or the broader community.

\section{Acknowledgement}

On the research, the authors would like to thank to Magister of Communication Science, FISIP, Universitas Sebelas Maret Surakarta who has supported and facilitated the process until the end of the report.

\section{References}

Baran, S. J., \& Davis, D. K. (2011). Mass Communication Theory: Foundations, Ferment, and Future. Cengage Learning.

Barker, R. T., \& Gower, K. (2010). Strategic Application of Storytelling in Organizations: Toward Effective Communication in a Diverse World. The Journal of Business Communication, 47(3), 295-312.

Bergemann, D., \& Bonatti, A. (2011). Targeting in Advertising Markets: Implications for Offline versus Online Media. The RAND Journal of Economics, 42(3), 417443.

Berger, P. L. (2011). The Sacred Canopy: Elements of a Sociological Theory of Religion. Open Road Media. Retrieved from https://www.google.com/books?hl=id\&lr=\&id=WcC-

AYOq6Q4C\&oi=fnd\&pg=PT9\&dq=Peter+L.+Berger+and+Thomas+Luckmann+ introduced+the+term+construction+of+reality\&ots=cicAsg8puD\&sig=eGDfq_EA 0x2wWytrzi9P3BD0HQQ

EB, G. A., \& SW, E. D. (2017). Hubungan Penggunaan Media Sosial dengan Tingkat Kepekaan Sosial di Usia Remaja. Jurnal The Messenger, 9(1), 65-69.

Fosnot, C. T. (2013). Constructivism: Theory, Perspectives, and Practice. Teachers College Press. Retrieved from https://www.google.com/books?hl=id\&lr=\&id=pIbAgAAQBAJ\&oi=fnd\&pg=PT7\&dq=Constructivism+2013\&ots=txIaWUqpBF \&sig=0a_q93QBymghxVPYbiOfiMv0eDg 
Griffin, E. A., Crossman, J., Bordia, S., Mills, C., Maras, S., Pearse, G., Shanahan, D. (2010). A First Look at Communication Theory, Em Griffin. Details. Boston: McGraw-Hill Higher Education.

Jin, Y., \& Liu, B. F. (2010). The Blog-Mediated Crisis Communication Model: Recommendations for Responding to Influential External Blogs. Journal of Public Relations Research, 22(4), 429-455.

Lau, R. W. (2012). Re-theorizing News' Construction of Reality: A Realist-DiscourseTheoretic Approach. Journalism, 13(7), 886-902.

Liputan6.com. (n.d.). Hoax Penculikan Anak Berujung Korban. Retrieved July 29, 2018, from https://www.liputan6.com/news/read/2902507/hoax-penculikan-anakberujung-korban

Littlejohn, S. W., \& Foss, K. A. (2010). Theories of Human Communication. Waveland Press. Retrieved from https://www.google.com/books?hl=id\&lr=\&id=dfUYAAAAQBAJ\&oi=fnd\&pg= PR3\&dq=littlejohn+human+communication+theory\&ots=a9CQWYZqi\&sig=mpG_TmJ7QCzz7k8eWfx $5 \mathrm{c} 1 \mathrm{mmY0}$

McCombs, M. (2014). Setting the Agenda: Mass Media and Public Opinion. John Wiley \& Sons. from https://www.google.com/books?hl=id\&lr=\&id=VAHXAgAAQBAJ\&oi=fnd\&pg= PT6\&dq=Many+aspects+of +the+influence+of+mass+media+perspective. $+\&$ ots $=$ xFXD9JUm3K\&sig=-qpQOVktHFfRm06ZDL8t4i6YWdE

Napoli, P. M. (2010). Revisiting 'Mass Communication'and the 'Work' of the Audience in the New Media Environment. Media, Culture \& Society, 32(3), 505-516.

Nguyen, A. (2010). Harnessing the Potential of Online News: Suggestions from a Study on the Relationship between Online News Advantages and Its Post-Adoption Consequences. Journalism, 11(2), 223-241.

Oliver, M. B., Dillard, J. P., Bae, K., \& Tamul, D. J. (2012). The Effect of Narrative News Format on Empathy for Stigmatized Groups. Journalism \& Mass Communication Quarterly, 89(2), 205-224.

Park, J., Stoel, L., \& Lennon, S. J. (2008). Cognitive, Affective and Conative Responses to Visual Simulation: The Effects of Rotation in Online Product Presentation. Journal of Consumer Behaviour, 7(1), 72-87.

Parthasarathi, V., Srinivas, A., Shukla, A., Chotani, S., Kovacs, A., Raman, A., ... others. (2012). Mapping Digital Media: India. London: Open Society Foundations. https://www.opensocietyfoundations. org/sites/default/files/mapping — digital — media - india-20130326.pdf.

Retrieved from https://internetdemocracy.in/wpcontent/uploads/2014/02/mapping-digital-media-india-20130326-2.pdf

Purwasito, A. (2017). Analisis Pesan. Jurnal The Messenger, 9(1), 103-109.

Rakhmat, J. (1985). Psikologi Komunikasi-cet. 29. Retrieved from http://openlibrary.telkomuniversity.ac.id/pustaka/98785/psikologi-komunikasicet-29.html

Soroka, S. N. (2012). The Gatekeeping Function: Distributions of Information in Media and the Real World. The Journal of Politics, 74(2), 514-528.

Street, J. (2010). Mass Media, Politics and Democracy. Palgrave Macmillan. Retrieved from

https://www.google.com/books?hl=id\&lr=\&id=sOkcBQAAQBAJ\&oi=fnd\&pg=P 
$\mathrm{P} 1 \& \mathrm{dq}=+$ the + mass + media $+2010 \&$ ots $=\mathrm{gm} 47 \mathrm{cfPTW} x \& \operatorname{sig}=\mathrm{v} 6 \mathrm{fgCt} 5 \mathrm{KL} 51 \mathrm{KPoK} 3 \mathrm{E}$ 6D431xJ2WQ

Ward, P., Clark, T., Zabriskie, R., \& Morris, T. (2012). Paper/Pencil versus Online Data Collection: An Exploratory Study. Journal of Leisure Research, 44(4), 507-530.

Wimmer, R. D., \& Dominick, J. R. (2013). Mass Media Research. Cengage learning. Retrieved from https://www.google.com/books?hl=id\&lr=\&id=FTukyzrOED0C\&oi=fnd\&pg=PP $1 \& d q=$ Media+exposure+-+audience+data++media+usage,+media+type,+frequency+\&ots=DpvEENQ8Bn\&sig=7EE9SNT9 mlY2VNJcHX2Sj9ATJrs 